\title{
Teaching Narrative Text by Using Story Telling Method at Ninth Grade Students
}

\author{
Anrasiyana \\ STKIP PGRI Sidoarjo, email : anrasiyanakurnia@gmail.com
}

\begin{abstract}
This study was purposed to know the implementation of storytelling in teaching narrative text in junior high school. This study used a quantitative method with a true experimental design. The subject of this study was the $9^{\text {th }}$ grade students at MTs. Miftahul Ulum BatangBatang. There were 42 students in this study; 21 of them were involved experimental class and 21 were involved to control class. Therefore, the speaking test and questionnaire were used as the research instrument in order to get the data. The test was conducted twice, pretest was done first and the second was posttest. The result of this study indicated that teaching narrative text by using story telling method was effective.
\end{abstract}

Keywords: teaching narrative text, speaking, storytelling

\section{INTRODUCTION}

The ability to speak confidently and fluently was something which students at MTs. Miftahul Ulum Batang-Batang would develop during their time at school, and something that would help them in their life. Speaking skill is defined as the skills which allow us to communicate effectively. But in reality the students in MTs. Miftahul Ulum had some problems in speaking skill. The problems were their vocabulary, grammar and their pronunciation was still poor. There were many factors that caused the problem of the students. They had limited access in their home because many of them lived in rural area and their motivation in learning English was still low and the most impact was about the method of the teacher in teaching in the class to create nice atmosphere for the students.

Speaking is to deliver a message to other and to make communication with society. In social activity communication was happen when there are two persons or more make communication and they understand what they are talking about. Basically there are important things aims of speaking (Tarigan H. G., 2008) namely : (a) to make communication and show new idea, knowledge or an important message; (b) to entertain means that listeners are amused by the story; (c) to persuade means that wants to make the listeners are aroused by the story; (d) to discuss means that the speaker wants to make discussion because the intention of the story is about making interaction between the listener and the speaker, so from the discussion will make a nice atmosphere.

According to (Rebecca, 2003) a narrative text is a text, which is logic and chronological order related events that are caused or experienced by many factors in the story itself. In addition, 
she explains that the narrative is a text telling a story and the purpose of the story is to amused the listener. According to (Widayati, 2003) in narrative, the story that is telling is an incident that really happened in reality. Sometimes the story of narrative text was a story that happened a minute ago or some years ago, a narrative text usually contains with features of characters, main character, setting, time, problem, solution and a plot (structure). In addition, there are many kinds of narrative text. They are myth, fairytales, aboriginal science, fiction, dreaming stories/ bedtime stories and romance novels. The purpose of the narrative text is to amuse or entertain the readers or listeners. Beside narrative text as the study material must be achieved by students of SMP in Indonesia, which is stated in curriculum 2013. A narrative text contains four structural organization that includes orientation, complication and resolution (Djatmika, 2013). In other word, narrative text contains some features that makes it different from other text which is conjunction to connect one event to other event, adverb (place, time), adverbial phrase and also the tenses that make the narrative text easy to remember uses past condition (past tense, pas perfect tense, past continues, etc) direct and indirect speech are include in narrative text.

One of way to teach narrative text is by using storytelling. Other way to teach cultural norm, culture, values, and attitude is by using storytelling. Learning is most effective when it applied with real action something that related to social and environment communication, so the knowledge will be applied directly and effectively. Sometimes, someone does not know how to apply their knowledge in their social. Today our education mostly is taking care about how the person in the social is. Story telling is one of the answers of the education's problems nowadays because it will teach students how to make communication around them and how to deliver the message in daily communication. Stories function as a tool to pass on knowledge on social context. According to (Nuraengsih, 2012) storytelling is a old method to make a child easily sleep in the night and also to amuse children when they were gather in the yard playing. Storytelling is intended to make someone is really come in to the story as if it was real. The storyteller must be active to attract the listener attentions'. Gesture, pronunciation, intonation and body language are very important in telling a story because it will influence listener attentions'. A good storyteller will make listener only focus to the story. Another opinion according to (Samantaray, June 2014) storytelling is the classic form of teaching having the potential to show of emotional intelligence and helps the child understand into human behavior which one is good and which one is not. Storytelling can also enrich learners' vocabulary and introduce them with new language. Moreover, storytelling can make children especially are happy in learning language and can make them interested without any anxiety in learning. 
By using storytelling the students can be brave to share their idea in action. They also can study how to deliver a message of the story and can comprehend the moral value by themselves without depend to the teacher. By story telling a students know how to attract the listener attentions' by making the story as interesting as well. Today, is not difficult thing to study about how to retelling a story well they learn it by you tube so they can explore what they can do. Storytelling can make the students more active and have more confidence to show their ability in retelling the story. So the teacher must give them a chance to develop their ability.

The purpose of applying storytelling in this study was to make students retell the narrative text easily and without conception it will be able to lead students speak up confidently. Based on the above statement, the objective of this study is to describe the implementation of teaching narrative text through storytelling as media of ninth grade students and to describe students' cognitive response in narrative text by using storytelling. Thus this study is aimed to know the effectiveness of storytelling in teaching narrative text for junior high school.

\section{METHOD}

The quantitative research was used in this research because it had statistical calculation to calculate the data. Furthermore, experimental design was used as a method to try a new technique in teaching narrative text through using storytelling in chosen classes. Two classes were used in this study, one as a control or comparison class and the other one as an experiment class. The class that was taught narrative text by using conventional method was called control class, the other one was the experimental class was taught narrative text using storytelling as the treatment. There were some reasons why the design was selected by the researcher. First, to know cause and effect relationship among the groups of the variables of this study, second to find out the effectiveness of using storytelling in teaching narrative text was the second purpose of this study, so the writer used true experimental. It was used because this study was taken the data from the subject as the experiment of this study.

The study used quasi-experimental design that did not randomly assign the participants as in true experimental. (Djarwanto, 1994) stated population is a number of person, thing, and animal in a group, usually it has same characteristics from one to others but sometimes it has different characteristics. In this side, the study made the population of the students where it can be divided in two classes control and experimental class of course by different characteristics.

Based on (Wani, p. 2002) a population refers to a group of human or no human such as object, education, geographic and time. Some statisticians call it universe. A population contains a number of a people in a specific place or time that among them are different from 
the sex, age, the color of the hair and other characteristics. But the differences of the characteristics make them in unity and make them unique and the researchers called them population. From the point, we know that population is a group of something that more than one and gather in one place and time.

In MTs. Mifathul Ulum there are twelve classes, but the researcher chose only two classes IX C and IX D. IX C as a control class and class IX D as an experiment class. In two classes, each class there was twenty one students. The writer would like to compare two classes. Experimental class received storytelling used in teaching narrative text, on the other hand, control class was taught by using conventional method in teaching and learning process. technique in teaching and learning process. In measuring their ability in retelling a story, both classes got pretest and posttest in the process. Moreover, instrumentation is the data that was got from the first the study was done until the study has found a conclusion or finding being attention of the researcher (Franenkel \& Wallen, 2000) To collect the data, the researcher used test (pretest and posttest) and also questionnaire to know the students' response in experimental class about the method.

The test using to collect students' score in this study was speaking test because the technique was storytelling. In the test, the teacher would give a narrative text about a legend and then asked the students to retell the story in front the class. To acquire students' score in retelling the narrative text, a scoring rubric formulated by (Hughes, 2003) was used in this research. The adapted scoring rubric consists of five aspects which are pronunciation, grammar, vocabulary, fluency, and expression. Questionnaire was the second instrument which consisted 5 questions. A closed ended question was used in this study to get the response from the students in experimental class. The questionnaire was given to know the feedback from the students after the treatment was done. It was given after the posttest was done in the experimental class.

In addition, this research conducted in five meetings first was pretest, second and third meeting were giving the class the treatment and the fourth and fifth was posttest and answering the questionnaire.

This study was conducted to know the effectiveness of storytelling technique in teaching narrative text by using two different samples. The data analysis used automatically calculation and analysis which was from the software Microsoft Excel 2007 and SPSS 20 that had the significance level of $5 \%(0,05)$. To obtain the contrast of the means scores experimental and control class students. There were normality, homogeneity and hypothesis whether H0 is rejected or not. It purposed to find the contrast of means of scores of both experimental and 
control class students', the T-test in which the two groups of larger samples correlated each other was used.

In this research the writer was the observer in the class. The writer observed the teacher in the class while teaching using two different methods with different subjects. Control class used conventional technique while experimental class used storytelling method in teaching narrative text.

\section{FINDING AND DISCUSSION}

Based on the first question, this chapter explains the pretest scores of experimental and control class, posttest scores' of experimental and control class and the result of effect size calculation. From this test it could be known whether there were differences before and after the treatment.

The observation or measurement process of students' score is described by $\mathrm{X}_{1}$ is students' score in pretest but $\mathrm{X}_{2}$ is the students' score in post test.

Table 1. The Result of Experimental class' Score

\begin{tabular}{|c|c|c|c|c|c|}
\hline NO. & $\begin{array}{c}\text { STUDENTS' } \\
\text { NAME }\end{array}$ & $\begin{array}{c}\text { PRE-TEST } \\
\mathrm{X}_{1}\end{array}$ & $\begin{array}{c}\text { POST- } \\
\text { TEST } \mathrm{X}_{2}\end{array}$ & $D=X_{1}-X_{2}$ & $D\left(X_{1}-X_{2}\right)^{2}$ \\
\hline 1 & $\mathrm{~A}$ & 65 & 75 & -10 & 100 \\
\hline 2 & B & 55 & 75 & -20 & 400 \\
\hline 3 & $\mathrm{C}$ & 60 & 80 & -20 & 400 \\
\hline 4 & D & 60 & 80 & -20 & 400 \\
\hline 5 & $\mathrm{E}$ & 65 & 80 & -15 & 225 \\
\hline 6 & $\mathrm{~F}$ & 70 & 85 & -15 & 225 \\
\hline 7 & $G$ & 65 & 85 & -20 & 400 \\
\hline 8 & $\mathrm{H}$ & 70 & 85 & -15 & 225 \\
\hline 9 & I & 60 & 80 & -20 & 400 \\
\hline 10 & $\mathrm{~J}$ & 55 & 75 & -20 & 400 \\
\hline 11 & K & 60 & 80 & -20 & 400 \\
\hline 12 & $\mathrm{~L}$ & 65 & 85 & -20 & 400 \\
\hline 13 & $\mathrm{M}$ & 70 & 80 & -10 & 100 \\
\hline 14 & $\mathrm{~N}$ & 65 & 90 & -25 & 625 \\
\hline 15 & $\mathrm{O}$ & 60 & 85 & -25 & 625 \\
\hline 16 & $\mathrm{P}$ & 50 & 80 & -30 & 900 \\
\hline 17 & Q & 50 & 85 & -35 & 1225 \\
\hline 18 & $\mathrm{R}$ & 65 & 80 & -15 & 225 \\
\hline 19 & $\mathrm{~S}$ & 70 & 80 & -10 & 100 \\
\hline 20 & $\mathrm{~T}$ & 65 & 85 & -20 & 400 \\
\hline
\end{tabular}




\begin{tabular}{|c|c|c|c|c|c|}
21 & $\mathrm{U}$ & 60 & 85 & -25 & 625 \\
\hline & SUM & 1305 & 1715 & -410 & 8800 \\
\hline & MEAN & 62.14285714 & 81.66666667 & 19.5238095 & 419.047619 \\
\hline & MAX. SCORE & 85 & 95 & & \\
\hline & MIN. SCORE & 20 & 40 & & \\
\hline
\end{tabular}

Table 2. The result of Control Class' Score

\begin{tabular}{|c|c|c|c|c|c|}
\hline & $\begin{array}{c}\text { STUDENTS' } \\
\text { NAME }\end{array}$ & $\begin{array}{c}\text { PRE-TEST } \\
\left(\mathrm{X}_{1}\right)\end{array}$ & $\begin{array}{c}\text { POST-TEST } \\
\left(\mathrm{X}_{2}\right)\end{array}$ & $\mathrm{D}=\mathrm{X}_{1}-\mathrm{X}_{2}$ & $\mathrm{D}\left(\mathrm{X}_{1}-\mathrm{X}_{2}\right)^{2}$ \\
\hline 1 & $\mathrm{~A}$ & 60 & 55 & 5 & 25 \\
\hline 2 & $\mathrm{~B}$ & 55 & 50 & 5 & 25 \\
\hline 3 & $\mathrm{C}$ & 65 & 60 & 5 & 25 \\
\hline 4 & $\mathrm{D}$ & 55 & 60 & 5 & 25 \\
\hline 5 & $\mathrm{E}$ & 60 & 65 & -5 & 25 \\
\hline 6 & $\mathrm{~F}$ & 65 & 60 & -5 & 25 \\
\hline 7 & $\mathrm{G}$ & 65 & 65 & 5 & 25 \\
\hline 8 & $\mathrm{H}$ & 65 & 60 & 0 & 0 \\
\hline 9 & $\mathrm{I}$ & 55 & 50 & 5 & 25 \\
\hline 10 & $\mathrm{~J}$ & 50 & 55 & 5 & 25 \\
\hline 11 & $\mathrm{~K}$ & 55 & 60 & -5 & 25 \\
\hline 12 & $\mathrm{~L}$ & 60 & 55 & -5 & 25 \\
\hline 13 & $\mathrm{M}$ & 65 & 60 & 5 & 25 \\
\hline 14 & $\mathrm{~N}$ & 60 & 60 & 5 & 25 \\
\hline 15 & $\mathrm{O}$ & 55 & 60 & 0 & 0 \\
\hline 16 & $\mathrm{P}$ & 40 & 50 & -5 & 25 \\
\hline 17 & $\mathrm{Q}$ & 45 & 45 & -10 & 100 \\
\hline 18 & $\mathrm{R}$ & 60 & 55 & 0 & 0 \\
\hline 19 & $\mathrm{~S}$ & 65 & 70 & 5 & 25 \\
\hline 20 & $\mathrm{~T}$ & 60 & 65 & -5 & 25 \\
\hline 21 & $\mathrm{U}$ & 55 & 60 & -5 & 25 \\
\hline & SUM & 1215 & 1220 & 5 & 525 \\
\hline & MEAN & 57.85714286 & 58.0952381 & 0.238095 & 25 \\
\hline & MAX. SCORE & 85 & 95 & & \\
\hline & MIN. SCORE & 20 & 40 & & \\
\hline & & & & & \\
\hline
\end{tabular}

Pretest was a test was used to get the score of the students before the treatment was done. The students' score were evaluated by using the scoring rubric adopted from (Hughes, 2003) There were a little difference between the experimental class mean and the control class. 
The mean of experimental class was 62,14 . On the other hand, the mean of control class was 57,90. This score was taken before the treatment was done in the experimental class.

\section{DISCUSSION}

After the treatment of storytelling technique in teaching narrative text we could see from the table above that the mean of experimental class was 81,6 on the other hand the mean of control class was 58,09. Two classes with different treatment of course the scores would be different. It means that after the treatment there was a better development in the score of experimental class rather than control class because this class was taught by using conventional teaching. There was different score between experimental class that using storytelling technique and the control class that used conventional technique.

The normality test the experimental class with chi square with significance level 0,05 with $\mathrm{T}_{\text {count }}(0,127)<\mathrm{T}_{\text {table }}(0,190)$ while the control class was $\mathrm{T}_{\text {count }}(0,185)<\mathrm{T}_{\text {table }}(0.190)$ which mean that the data was distributed normally. And the homogeneity of experimental and control class score with the significance level 0,05 with $\mathrm{T}_{\text {count }}(1,29)<\mathrm{T}_{\text {table }}(2,12)$ which mean that two variables were homogeny.

Furthermore, it was also supported by independent t-test that got from the posttest of experimental class can be concluded $\mathrm{T}_{\text {count }}(39,76)>\mathrm{T}_{\text {table }}(2,086)$ which mean the H0 was rejected and Ha was accepted. It can be said that storytelling was effective to teach narrative text. Based on the data we could see that there was significant development of the score of the experimental class after the treatment was done in the ninth class of MTs. Miftahul Ulum academic year 2021/2022.

The pretest and the posttest scores of the experimental and control class revealed that both classes have the normal and almost equal scores. In addition, the independent t-test computation of pretest and posttest scores for experimental and control class indicated that there was a significant difference between their score the experimental class scores were more significant than control class scores. Pretest mean for experimental class was 61,14 while in the posttest was 81,66. Meanwhile pretest mean for control class was 57,90 while posttest mean was 58,09. It was clear that posttest for experimental class was bigger than posttest mean for control group. It means that the experimental class had bigger improvement than the control class.

Furthermore, the data statistic calculation of the pretest scores suggested that the distribution data in both group was normal. And the variance of them was homogenous. Based 
on the result above, it could be said that the storytelling method in teaching narrative text was proven to be successful to help improving students' ability in retelling narrative text.

Questionnaire was the second instrument of this research. It was used to know the effectiveness of storytelling method in teaching narrative text. The questionnaire was given to the experimental class after they did the posttest. There were 5 questions with close ended questions given to the students. Then this formula was used to analyzed the result of the students' answer:

$$
p=\frac{f}{n} x 100
$$

The result of the questionnaire number 1 showed that there were 21(100\%) students who agreed that storytelling could increase their interest in learning narrative text by retelling it in front of their friend. It can make them have more confidence in retelling story.

The result of questionnaire number two revealed that all of the students agreed that storytelling was effective in teaching narrative text. It can make them easier in understanding the text.

17 students $(80,9 \%)$ agreed that their speaking improved after they retelling the story and they can add their vocabulary automatically and 4 students $(19,1 \%)$ did not agreed that their speaking was improved after retelling the story. This was the output of the questionnaire number 3 .

As the result number 4 all of the students agreed that storytelling can make them retelling the story by understanding the story.

The last questionnaire, all of the students also agreed that storytelling can make them easily catching the moral value of the story by listening the story.

Hence, the overall result of the questionnaire has indicated that storytelling in teaching narrative text was effective.

\section{CONCLUSION}

Based on the research question that this research was conducted to know the effectiveness of the storytelling method in teaching narrative text. From the finding and the discussion above it can be concluded that storytelling has been proved as the effective technique or method in teaching narrative text. This result was evaluated statistically by the calculation of independent t-test using IBM SPSS statistics v.20. Moreover, the experimental class' score in posttest has indicated that their comprehending about narrative text was improved especially in 
retelling the story in front of their friends. It can be seen from the mean that was got by the experimental class 81,6 in the posttest after the treatment was done in the class.

In addition the researcher used the questionnaire to collect the data. The questionnaire's result showed that the used of storytelling method in teaching narrative text was effective. All the students agreed to use storytelling as one of the method ion teaching narrative text in their class and made them had more confidence and also could improve their vocabulary. They also agreed they their understanding about the story was better because they knew deeply about the story and they could catch the moral value easily.

The result of this study will be expected in contribution for the students and also next researcher. For the students, this study will be useful for them to make them have more confidence their ability in speaking especially in retelling a story. This method can be a reference for them to improve their vocabulary. For teachers this method can be a solution in teaching the students in narrative text. More creative we teach our students the result will be better than before. Storytelling is a fun way in teaching, our students will be interest to understand the story without any force. The space of our classroom will be more live because it is our turn to see their performance in front of the class.

\section{REFERENCES}

Arikunto, S. (2006). Metode Penelitian; Prosedur penelitian suatu pendekatan Praktik. Jakarta: Rineka Cipta.

Darmawan, D. (2003). metode penelitian Kuantitatif. Bandung: PT. Remaja Rosdakarya.

Djarwanto. (1994). Pokok-Pokok Metode Riset dan Bimbingan Teknis penulisan Skripsi. Yogyakarta: Liberty.

Djatmika. (2013). Writing Narrative text. Bandung: Pakar Raya Pakarnya Pustaka.

Franenkel, j. R., \& Wallen, N. E. (2000). How to Design and Evaluate Research in Education. Boston: McGraw-hill.

Hughes, a. (2003). Testing for Language teacher. Cambridge: Cambridge university Press.

Nuraengsih. (2012). The Use Story Telling Technique to Improve Students' Motivation and Speaking Skill. Vol.1 (1), 1.

Rebecca, J. L. (2003). A Critical Handbook of Children's Literature. - , - . 
Samantaray, P. (June 2014). Use of Story Telling Method to Develop Spoken English Skill. International Journal of Language \& Linguistics, Vol 1 No. 1.

Sudjana. (2005). Metode Statistika. Bandung: Tarsito.

Tarigan, H. G. (2008). Berbicara Sebagai suatu Keterampilan Berbahasa. Bandung: Angkasa.

Thornburry, S. (2005). How to teach Speaking. England: Person Limited Education.

Wani, S. R. Research Metodology/sampling. M.A Edu, DDE, KU, 190002, J\&K.

Widayati, S. (2003). Pembelajaran dan Evaluasi Writing. Jakarta: Departemen pendidikan \& Kebudayaan Direktorat Jenderal Pendidikan Tinggi. 